\title{
Sexual Victimization in Prisons and Jails Reported by Inmates, 2011-12
}

Supplemental Tables: Prevalence of Sexual Victimization Among Transgender Adult Inmates

Allen J. Beck, Ph.D.

BJS Statistician

December 2014, NCJ 241399 


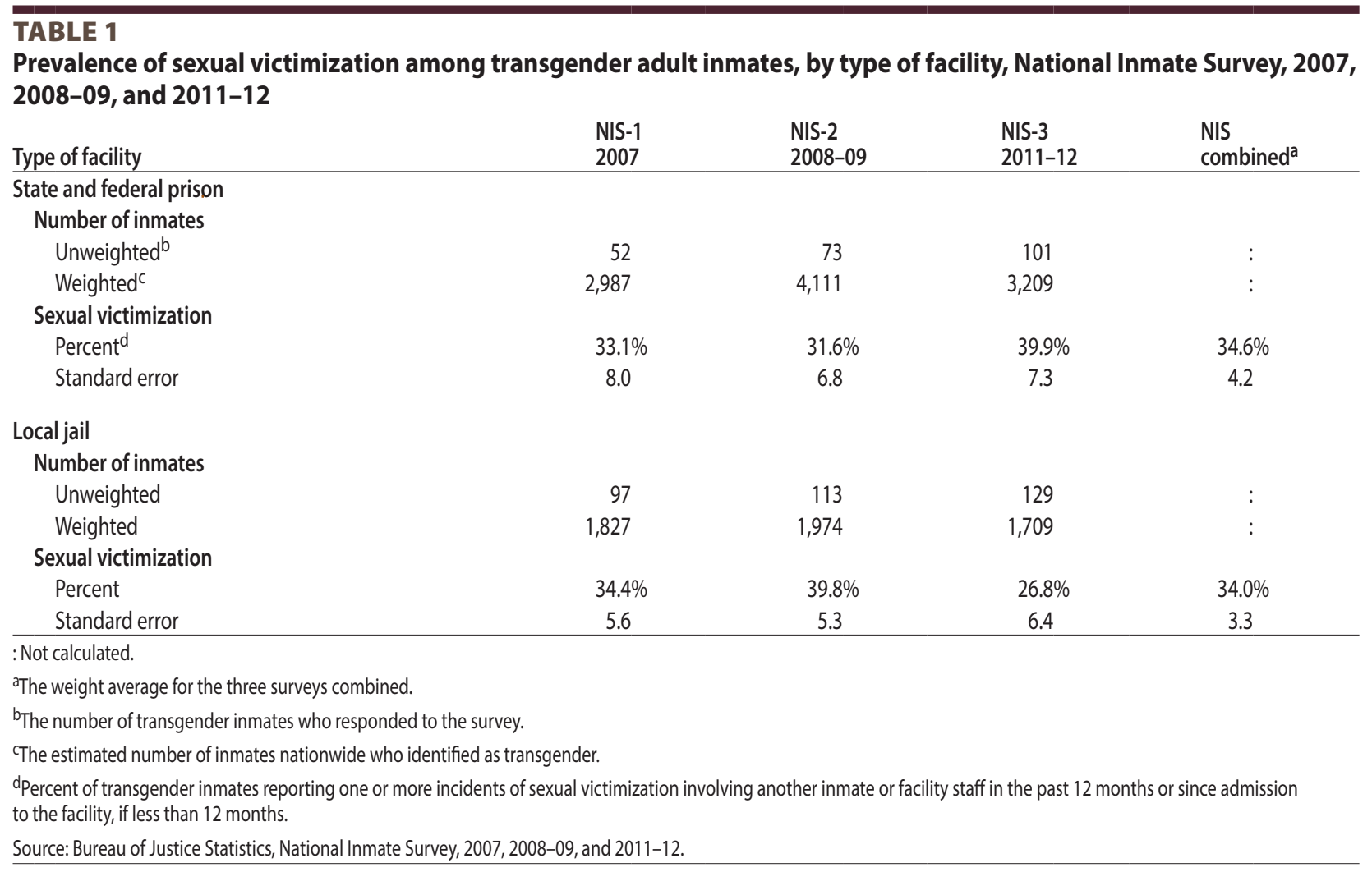

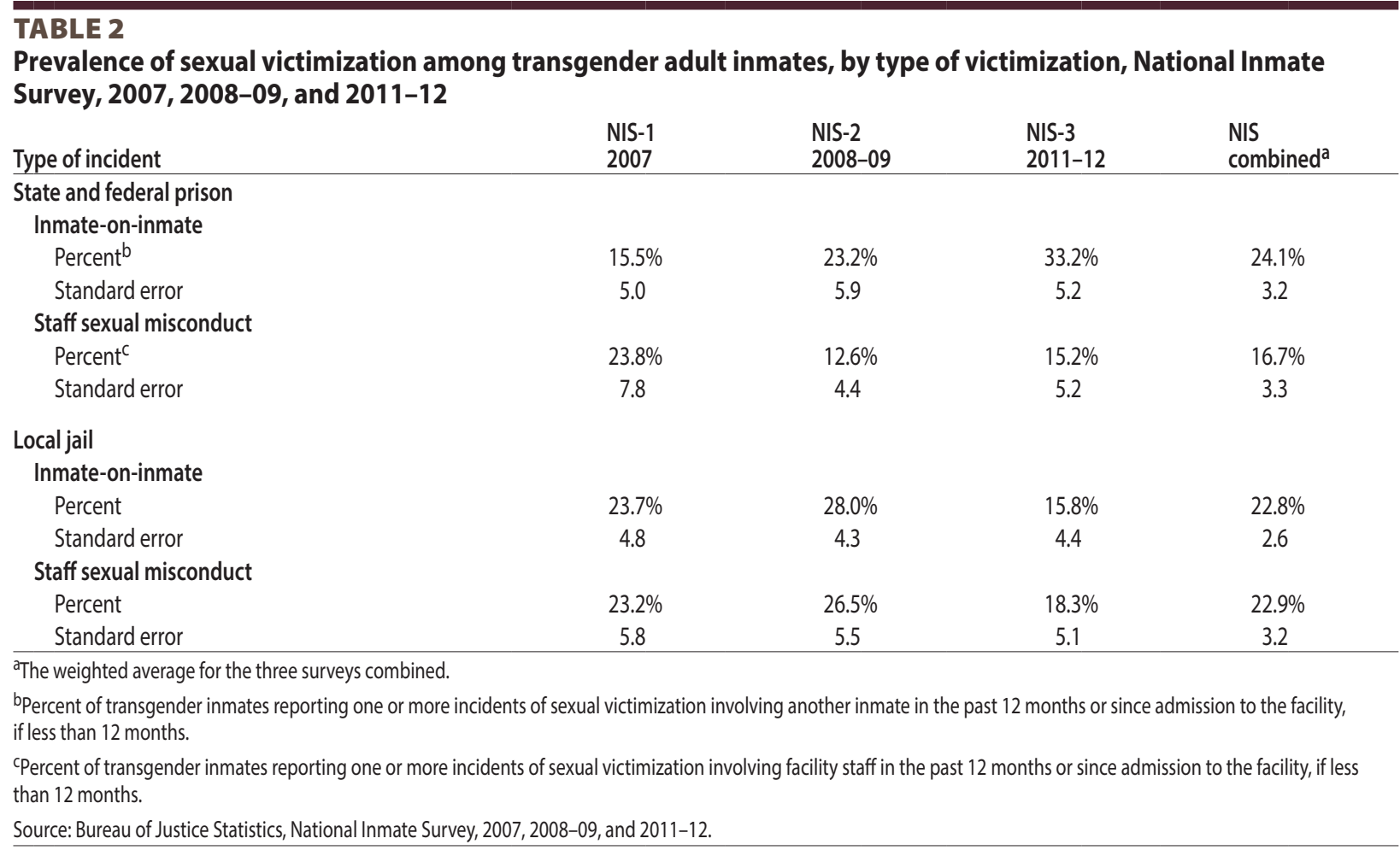


